\title{
Evaluation of Direct and Indirect Methods of Sub-Neoglottic Pressure Measurement in Tracheoesophageal Speakers: A Systematic Review and Meta-Analysis
}

\author{
Shekaraiah Sheela ${ }^{\mathrm{a}}$ Venkataraja U. Aithal $^{\mathrm{a}}$ Bellur Rajashekhar $^{\mathrm{a}}$ \\ Melissa Glenda Lewis ${ }^{b}$

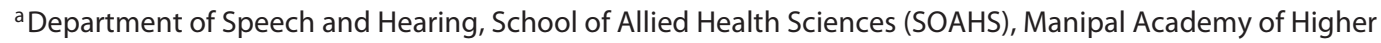 \\ Education, Manipal, India; ${ }^{b}$ Department of Statistics, Manipal Academy of Higher Education, Manipal, India
}

\section{Keywords}

Sub-neoglottic pressure - Tracheoesophageal speech .

Voice prosthesis $\cdot$ Systematic review

\begin{abstract}
Objective: Tracheoesophageal (TE) prosthetic voice is one of the voice restoration options for individuals who have undergone a total laryngectomy. Aerodynamic analysis of the TE voice provides insight into the physiological changes that occur at the level of the neoglottis with voice prosthesis in situ. The present study is a systematic review and meta-analysis of sub-neoglottic pressure (SNP) measurement in TE speakers by direct and indirect methods. Patients and Methods: The screening of abstracts and titles was carried out for inclusion of articles using 10 electronic databases spanning the period from 1979 to 2016. Ten articles which met the inclusion criteria were considered for meta-analysis with a pooled age range of 40-83 years. Results: The pooled mean SNP obtained from the direct measurement method was $53.80 \mathrm{~cm} \mathrm{H}_{2} \mathrm{O}$ with a $95 \%$ confidence interval of 21.14-86.46 $\mathrm{cm} \mathrm{H}_{2} \mathrm{O}$, while for the indirect measurement method, the mean SNP was $23.55 \mathrm{~cm} \mathrm{H}_{2} \mathrm{O}$ with a $95 \%$ confidence interval of 19.23-27.87 $\mathrm{cm} \mathrm{H}_{2} \mathrm{O}$. Conclusion: Based on the literature
\end{abstract}

\section{KARGER}

() 2017 S. Karger AG, Basel

E-Mail karger@karger.com

www.karger.com/fpl review, the various procedures followed for direct and indirect measurements of SNP contributed to a range of differences in outcome measures. The meta-analysis revealed that the "interpolation method" for indirect estimation of SNP was the most acceptable and valid method in TE speakers.

(c) 2017 S. Karger AG, Basel

\section{Introduction}

Laryngeal aerodynamics deals with the measurement of airflow and pressure produced by laryngeal voice production [1]. It is considered an essential tool for clinical voice evaluation [2]. Tracheoesophageal (TE) prosthetic voice is one of the most preferred alaryngeal voice restoration options for individuals who have undergone a total laryngectomy [3]. Air from the lungs is shunted into the esophagus via the one-way valve of the voice prosthesis to vibrate the pharyngoesophageal (PE) segment to produce voice.

Aerodynamic analysis of TE voice can provide insight into the physiological changes at the level of the PE segment (also called neoglottis) with the prosthesis in situ. In other words, it is presumed to provide a perspective as 
to the neoglottic valving efficiency of voicing. Some of these aerodynamic measures are maximum phonation duration, s/z ratio, sub-neoglottic pressure (SNP, cm $\left.\mathrm{H}_{2} \mathrm{O}\right)$, mean airflow rate $(\mathrm{L} / \mathrm{s})$, neoglottic airway resistance $\left(\mathrm{cm} \mathrm{H}_{2} \mathrm{O} / \mathrm{L} / \mathrm{s}\right)$, and neoglottic airway conductance ( $\left.\mathrm{L} / \mathrm{s} / \mathrm{cm} \mathrm{H}_{2} \mathrm{O}\right)$.

SNP is an important aerodynamic measure in voicing. The SNP is the air pressure below the PE segment developed by the respiratory system for TE speech production [4]. Similar to subglottal pressure (SGP), SNP can be commonly measured in $\mathrm{cm} \mathrm{H}_{2} \mathrm{O}$ [1] using direct and indirect methods. In the direct method, one of the procedures involves measurement by placing a hypodermic needle into the tracheostoma in the anterior neck. The needle is externally connected to a pressure transducer by a thin, relatively short piece of polyethylene tubing to measure SNP [5]. The second method involves placing a miniaturized pressure transducer in the neoglottis through the nostril [6] and making the measurement. Among indirect methods, the "intraesophageal pressure balloon" method involves inserting a deflated balloonlike device connected to a catheter tube transnasally into the esophagus at the mid-thoracic level. The catheter is connected to a pressure transducer and the balloon is slightly inflated. The intratracheal pressure $\left(\mathrm{cm} \mathrm{H}_{2} \mathrm{O}\right)$ (approximately equal to SGP) is transmitted to the balloon via the posterior tracheal wall, which is attached to the anterior esophageal wall [7-9].

In each of the methods described above, the procedures are more or less invasive, and for routine practice in clinical settings, a method needs to be simple and noninvasive. There are two indirect, noninvasive methods available and desirable. The "airway interruption method" [10] is based on the air pressure in the airway during the sudden interruption of vowel sound production. In this procedure, repeated syllables of /pi/ are used to estimate the SGP during the vowel segment /i/ between the consonants at a constant pitch and at a rate of 1.5 syllables per second. During the production of /i/, the vocal folds are vibrating, the lips are open, and intraoral pressure (IOP) is equal to the atmospheric pressure. Before the release of the plosive /p/, the lips are closed, the vocal cords are open, and SGP and IOP are equal. In the second method, referred to as the "interpolation method" [11], estimation is based upon the peak IOP during production of $/ \mathrm{p} /$ surrounded by vowels. The pressure measurement directly indicates the power of the air supply to the phonatory mechanism. The stronger the air supply, the higher the pressure values [4].
Table 1. "Keywords" used to identify the primary studies

\#1 “Direct method", "Direct methodology", "Direct evaluation", "Direct calculation", "Direct measurement"

\#2 "Indirect method", "Indirect methodology", "Indirect evaluation", "Indirect calculation", "Indirect measurement"

\#3 "Sub-neoglottic pressure", "Tracheal pressure", "Endotracheal pressure", "Endo-tracheal pressure", "Intratracheal pressure", "Intra-tracheal pressure", "Esophageal pressure", "Endoesophageal Pressure", "Endo-esophageal Pressure", "Intraesophageal pressure", "Intra-esophageal pressure", "Subpseudoglottic pressure", "Sub-pseudoglottic pressure", "Sub-pseudo-glottic pressure", "Sub-neoglottal pressure", "Sub-pharyngoesophageal pressure", "Oral pressure", "Intraoral pressure", "Intra-oral pressure", "Articulatory pressure"

\#4 “Tracheo-esophageal speakers”, “Tracheoesophageal speakers", "Tracheoesophageal prosthetic voice users", "Tracheoesophageal voice speakers", "Tracheoesophageal speech users", "Tracheoesophageal voice prosthesis users", "Tracheoesophageal voice prosthesis speakers", "Voice prosthesis users", "Voice prosthesis speakers",

"Tracheo-esophageal puncture speakers", "Tracheoesophageal puncture users", "Speech prosthesis users"

\section{Need for the Study}

Subsequent to total laryngectomy, patients exhibit differences in the anatomical and functional aspects of their respiratory, phonatory, and digestive systems. The innate function of the PE segment is to maintain tonicity of the cricopharyngeal muscle, thereby preventing gastroesophageal reflux [12]. Individuals who have undergone a total laryngectomy depend on the PE segment for voice production. Aerodynamic analysis of subsequent voice production captures the relation between respiratory and laryngeal system functions during TE voice production. Unlike the true vocal folds, the PE segment has a very different vibrating mechanism principle for voice production. The mass, length, and tension of the true vocal folds can be manipulated in normal laryngeal speakers, while the PE segment is under little voluntary control [13]. The vibration of the tonic PE segment needs more pressure for producing sound than that required for phonation with the true vocal folds [14]. This warrants the need to consider SNP $\left(\mathrm{cm} \mathrm{H}_{2} \mathrm{O}\right)$ as a standard objective measure in prosthetic aided voice rehabilitation.

Several studies have pointed out the accuracy of estimation method of SNP measurement for clinical and research purposes [15-17]. The accuracy of the indirect 
Table 2. Quality assessment of primary studies included

\begin{tabular}{|c|c|c|c|c|c|c|c|c|c|c|}
\hline \multirow[t]{2}{*}{ Quality assessment criteria } & \multicolumn{10}{|c|}{ Reference number } \\
\hline & 20 & 21 & $22^{\mathrm{a}}$ & 23 & 24 & 25 & 26 & 4 & 27 & 28 \\
\hline Clear presentation of design & $\mathrm{Y}$ & $\mathrm{Y}$ & $\mathrm{Y}$ & $\mathrm{Y}$ & $\mathrm{Y}$ & $\mathrm{Y}$ & $\mathrm{Y}$ & $\mathrm{Y}$ & $\mathrm{Y}$ & $\mathrm{Y}$ \\
\hline Appropriate design & $\mathrm{Y}$ & $\mathrm{Y}$ & $\mathrm{Y}$ & $\mathrm{Y}$ & $\mathrm{Y}$ & $\mathrm{Y}$ & $\mathrm{Y}$ & $\mathrm{Y}$ & $\mathrm{Y}$ & $\mathrm{Y}$ \\
\hline Appropriate inclusionary and exclusionary criteria & $\mathrm{Y}$ & $\mathrm{Y}$ & $\mathrm{Y}$ & $\mathrm{Y}$ & $\mathrm{Y}$ & $\mathrm{Y}$ & $\mathrm{Y}$ & $\mathrm{Y}$ & $\mathrm{Y}$ & $\mathrm{Y}$ \\
\hline Appropriate experimental methods & $\mathrm{Y}$ & $\mathrm{Y}$ & $\mathrm{Y}$ & $\mathrm{Y}$ & $\mathrm{Y}$ & $\mathrm{Y}$ & $\mathrm{Y}$ & $\mathrm{Y}$ & $\mathrm{Y}$ & $\mathrm{Y}$ \\
\hline Clear outcome measures & $\mathrm{Y}$ & $\mathrm{Y}$ & Y & $\mathrm{Y}$ & Y & $\mathrm{Y}$ & $\mathrm{Y}$ & $\mathrm{Y}$ & $\mathrm{Y}$ & $\mathrm{Y}$ \\
\hline Appropriate outcome measures & $\mathrm{Y}$ & $\mathrm{Y}$ & $\mathrm{Y}$ & $\mathrm{Y}$ & $\mathrm{Y}$ & $\mathrm{Y}$ & $\mathrm{Y}$ & $\mathrm{Y}$ & $\mathrm{Y}$ & $\mathrm{Y}$ \\
\hline Measurement of interrater reliability & $\mathrm{N}$ & $\mathrm{N}$ & $\mathrm{N}$ & $\mathrm{N}$ & $\mathrm{N}$ & $\mathrm{N}$ & $\mathrm{N}$ & $\mathrm{N}$ & $\mathrm{N}$ & $\mathrm{N}$ \\
\hline Adherence to protocol & $\mathrm{Y}$ & $\mathrm{Y}$ & $\mathrm{Y}$ & $\mathrm{Y}$ & $\mathrm{Y}$ & $\mathrm{Y}$ & $\mathrm{Y}$ & $\mathrm{Y}$ & $\mathrm{Y}$ & $\mathrm{Y}$ \\
\hline Clear data analysis & $\mathrm{Y}$ & $\mathrm{Y}$ & $\mathrm{Y}$ & $\mathrm{Y}$ & $\mathrm{Y}$ & $\mathrm{Y}$ & $\mathrm{Y}$ & $\mathrm{Y}$ & $\mathrm{Y}$ & $\mathrm{Y}$ \\
\hline Appropriate data analysis & $\mathrm{Y}$ & $\mathrm{Y}$ & $\mathrm{Y}$ & $\mathrm{Y}$ & $\mathrm{Y}$ & $\mathrm{Y}$ & $\mathrm{Y}$ & $\mathrm{Y}$ & $\mathrm{Y}$ & $\mathrm{Y}$ \\
\hline
\end{tabular}

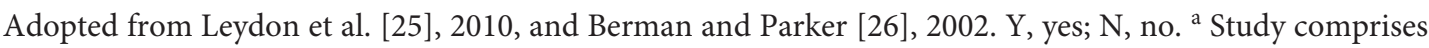
both direct and indirect measurement methods of SNP $\left(\mathrm{cm} \mathrm{H}_{2} \mathrm{O}\right)$ findings.

method of estimating SGP $\left(\mathrm{cm} \mathrm{H}_{2} \mathrm{O}\right)$ has been reported in normal laryngeal speakers [18-20], individuals with vocal fold paralysis, and individuals who have undergone a partial laryngectomy [21]. Those studies compared the direct and indirect SGP $\left(\mathrm{cm} \mathrm{H}_{2} \mathrm{O}\right)$ measurement methods and reported minimal differences between them. However, in TE speakers, there is a paucity of information regarding SNP $\left(\mathrm{cm} \mathrm{H}_{2} \mathrm{O}\right)$ in direct and indirect measurement methods. The current systematic review and metaanalysis provides information on various methods used in the direct and indirect estimation of SNP in the clinical evaluation of TE voice. The information obtained from this review should contribute to the knowledge of clinicians working with this population.

\section{Methods}

\section{Study Selection Criteria}

Published studies involving only original data that satisfied the following criteria were considered: (1) SNP $\left(\mathrm{cm} \mathrm{H}_{2} \mathrm{O}\right)$ should be the target parameter measured, (2) both male and/or female TE speakers aged 18 years and older were considered, (3) studies with the objective of measuring $\mathrm{SNP}\left(\mathrm{cm} \mathrm{H}_{2} \mathrm{O}\right)$ using direct and/or indirect methods at a comfortable pitch and loudness were permitted, and (4) the measured parameters of all the studies had to include a mean and standard deviation of SNP $\left(\mathrm{cm} \mathrm{H}_{2} \mathrm{O}\right)$. The rationale behind this criterion was to provide the pooled mean and confidence interval (CI) at a comfortable pitch and loudness level specific to evaluation methods following meta-analysis. In addition, studies involving all types of research study designs were included. Aerodynamic studies performed in vitro and other alaryngeal voice restoration modes (esophageal speech, artificial larynx, gastric speech, buccal speech, and ASAI speech) were excluded.

\section{Search Strategy}

The literature search strategy followed the PICO Model, where $\mathrm{P}$ (Population of interest) is tracheoesophageal speakers, I (Intervention) is not applicable, $\mathrm{C}$ (Comparison) is between evaluation of direct and indirect methods, and O (Outcome) is SNP measurement. Cochrane collaboration [22] and preferred reporting items for systematic review and meta-analyses (PRISMA) guidelines [23] were followed to carry out the study. Electronic databases such as Cochrane Central Register of Control Trials (CENTRAL), Cumulative Index to Nursing and Allied Health Literature (CINHAL), Educational Resources and Information Centre (ERIC), IndMED, Ovid SP, ProQuest Medical Library, PubMed/Medline, Science Direct, Scopus, and Web of Science were used for the title, abstract, and fulltext screening by 2 independent reviewers (S.S. and V.U.A.). Using a systematic search, articles published between 1950 and 2016 were identified and reviewed. Though the first voice prosthesis was commercially available during 1979 [24], the search filter in the current study was set at "1950" to rule out any preliminary research undertaken related to voice prostheses. A combination of keywords (Table 1) was used to identify the primary studies. These keywords were used to develop search strings as per the requirements of the databases using Boolean operators (AND, OR). Following title and abstract screening, full-text version of those studies meeting the inclusion criteria were reviewed (S.S. and V.U.A.). Manual search of various journals did not provide any additional relevant studies (S.S. and B.R.). In total, 10 studies were included in the meta-analysis.

\section{Data Extraction and Management}

Two studies were identified that used a direct method of measuring SNP $\left(\mathrm{cm} \mathrm{H}_{2} \mathrm{O}\right)$, and 7 used an indirect method. There was 1 study with both measurement methods. Therefore, the count for the direct measurement method was 3 and the count for the indirect measurement method was 8 . SNP values were converted to a common measurement unit (i.e., $\mathrm{cm} \mathrm{H}_{2} \mathrm{O}$ ) for direct comparison across studies (S.S. and V.U.A.). The data extracted from the studies included name of author(s), year of publication, sample size, and mean and standard deviation of SNP $\left(\mathrm{cm} \mathrm{H}_{2} \mathrm{O}\right)$ and were or- 
Table 3. Studies included for the systematic review and meta-analysis of direct measurement methods of SNP $\left(\mathrm{cm} \mathrm{H}_{2} \mathrm{O}\right)$ in TE speakers

\begin{tabular}{|c|c|c|c|}
\hline $\begin{array}{l}\text { Authors } \\
\text { [Ref.], year }\end{array}$ & $\begin{array}{l}\text { Study design/Participants/Age range/ } \\
\text { Inclusion criteria }\end{array}$ & Type of direct method/instrument used & $\begin{array}{l}\text { Type of } \\
\text { task }\end{array}$ \\
\hline $\begin{array}{l}\text { Moon and } \\
\text { Weinberg } \\
{[29], 1987}\end{array}$ & $\begin{array}{l}\text { Cross-sectional study design } \\
n=5,(3 \text { male, } 2 \text { female); } 45-63 \text { years } \\
\text { Inclusion criteria: TE speech as the } \\
\text { primary method of communication } \\
\text { Use of tracheostoma valve at the time } \\
\text { of the experiment } \\
2 \text { subjects: Bivona low resistance, } 2 \\
\text { subjects: } 20 \text {-Fr home-made prototype by } \\
\text { Blom; } 1 \text { subject Blom-Singer duck bill }\end{array}$ & $\begin{array}{l}\text { Intratracheal pressure method } \\
\text { Insertion of } 14-\mathrm{G} \text { hypodermic needle in the trachea through } \\
\text { a modified (slightly extended) tracheostomal breathing valve } \\
\text { housing connected to differential pressure transducer (Setra } \\
\text { Model } 239 \mathrm{E} \text { pressure transducer), amplified and low-pass } \\
\text { filtered at } 100 \mathrm{~Hz} \text { (Accudata model } 109 \mathrm{DC} \text { amplifier), and } \\
\text { recorded on a sound channel of the FM tape recorder } \\
\text { Pressure measurement system calibration using U-tube water } \\
\text { manometer }\end{array}$ & $\begin{array}{l}\text { Sustained } \\
\text { vowel /a/ }\end{array}$ \\
\hline $\begin{array}{l}\text { Schutte and } \\
\text { Nieboer }[28] \\
2002\end{array}$ & $\begin{array}{l}\text { Cross-sectional study design } \\
n=18 ; 40-83 \text { years (mean } 62.3 \text { years) } \\
\text { Inclusion criteria: all TE speakers with } \\
\text { Groningen voice prosthesis }\end{array}$ & $\begin{array}{l}\text { Intatracheal pressure method } \\
\text { Open polyethylene catheter (outside diameter, } 2.0 \mathrm{~mm} \text {; } \\
\text { inside diameter, } 1.4 \mathrm{~mm} \text {; length, } 1.4 \mathrm{~m} \text { ) was inserted into } \\
\text { the tracheostoma and was held by the patient him/herself } \\
\text { under digital occlusion of the tracheostoma. The proximal } \\
\text { end of the catheter was connected to a differential pressure } \\
\text { transducer (Hewlett Packard } 267 \mathrm{BC} \text { ) coupled to a carrier } \\
\text { amplifier (Hewlett Packard } 8805 \mathrm{~B} \text { ) } \\
\text { Pressure measuring system calibration was done using a } \\
\text { U-shaped water manometer }\end{array}$ & $\begin{array}{l}\text { Sustained } \\
\text { vowel /a/ }\end{array}$ \\
\hline $\begin{array}{l}\text { Grolman } \\
\text { et al. [27], } \\
2007\end{array}$ & $\begin{array}{l}\text { Cross-sectional study design } \\
n=8 \\
\text { Inclusion criteria: all TE speakers had to } \\
\text { be tracheostoma valve users in daily life }\end{array}$ & $\begin{array}{l}\text { Intratracheal pressure method } \\
\text { The calibrated pressure transducer (Setra System Inc., } \\
\text { Action, MA, USA) was connected to the tracheostoma using } \\
\text { a modified Blom-Singer tracheostoma valve housing }\end{array}$ & $\begin{array}{l}\text { Sustained } \\
\text { vowel /a/ }\end{array}$ \\
\hline
\end{tabular}

ganized into a data extraction sheet. For all TE speakers, the ages across studies ranged from 40 to 83 years. As all the data required to answer the study questions have been published within research articles, no communication with authors was considered necessary. Quality assessment of the articles was completed using an assessment survey (Table 2) adopted from an earlier systematic review and meta-analysis $[25,26]$. Two blinded raters were included for the evaluation of the methodological quality of the studies. A third rater served as an arbiter when disagreements occurred.

\section{Statistical Analysis}

Pooled mean and 95\% CI were computed for SNP $\left(\mathrm{cm} \mathrm{H}_{2} \mathrm{O}\right)$. "Stata 13" statistical software was used for meta-analysis. Analysis was carried out with the assumption of a "random effect model" providing a more representative estimate than a fixed effect model. Heterogeneity was assessed using $\chi^{2} Q$ statistics and heterogeneity index $I^{2}$ (M.G.L.).

\section{Results}

Tables 3 and 4 present the details of the studies included in the current review of direct and indirect measurement methods of SNP $\left(\mathrm{cm} \mathrm{H}_{2} \mathrm{O}\right)$ in TE speakers. The pooled means of $\mathrm{SNP}\left(\mathrm{cm} \mathrm{H}_{2} \mathrm{O}\right), \mathrm{CI}, \mathrm{Q}$, and $I^{2}$ values were obtained from direct and indirect measurement methods in TE speakers. Three studies with a sample size of 31 qualified for meta-analysis of SNP $\left(\mathrm{cm} \mathrm{H}_{2} \mathrm{O}\right)$ obtained from the direct measurement method. The pooled mean was $53.80 \mathrm{~cm} \mathrm{H}_{2} \mathrm{O}$ with a $95 \% \mathrm{CI}$ of $21.14-86.46 \mathrm{~cm} \mathrm{H}_{2} \mathrm{O}$. There was a significant moderate heterogeneity in the results $\left(I^{2}=96.9 \%, p \leq 0.01\right)$. The forest plot of $\mathrm{SNP} \mathrm{cm} \mathrm{H}_{2} \mathrm{O}$ obtained from the direct method is shown in Figure 1.

Eight studies with a sample size of 66 qualified for meta-analysis of SNP $\left(\mathrm{cm} \mathrm{H}_{2} \mathrm{O}\right)$ obtained from the indirect method. The pooled mean was $23.55 \mathrm{~cm} \mathrm{H}_{2} \mathrm{O}$ with a $95 \%$ $\mathrm{CI}$ of $19.23-27.87 \mathrm{~cm} \mathrm{H}_{2} \mathrm{O}$. There was high heterogeneity in the results $\left(I^{2}=88.05 \%, p \leq 0.01\right)$. The forest plot of $\mathrm{SNP}\left(\mathrm{cm} \mathrm{H}_{2} \mathrm{O}\right)$ obtained from the indirect measurement method is shown in Figure 2.

\section{Discussion}

SNP has been accepted as an important aerodynamic measure to understand the vibratory characteristics of the PE segment. An accurate measure of SNP enhances the 
Table 4. Studies included for the systematic review and meta-analysis of indirect measurement methods of SNP $\left(\mathrm{cm} \mathrm{H}_{2} \mathrm{O}\right)$ in TE speakers

\begin{tabular}{|c|c|c|c|}
\hline $\begin{array}{l}\text { Authors [Ref.], } \\
\text { year }\end{array}$ & $\begin{array}{l}\text { Study design/Participants/ } \\
\text { Inclusion criteria }\end{array}$ & Type of indirect method/instrument used & Type of task \\
\hline $\begin{array}{l}\text { Weinberg et al. } \\
{[13], 1982}\end{array}$ & $\begin{array}{l}\text { Cross-sectional study design } \\
n=18 ; \text { male } \\
\text { Inclusion criteria: all TE speakers } \\
\text { with Blom-Singer voice prosthesis }\end{array}$ & $\begin{array}{l}\text { Intraesophageal pressure method } \\
\text { Catheter assembly was inserted into the base of voice } \\
\text { prosthesis, which was connected to the pressure transducer } \\
\text { (Statham PM197) } \\
\text { Pressure measuring system calibration was done using a } \\
\text { U-shaped water manometer }\end{array}$ & $\begin{array}{l}\text { Sustained } \\
\text { vowel /a/ }\end{array}$ \\
\hline $\begin{array}{l}\text { Motta et al. } \\
{[30], 2001}\end{array}$ & $\begin{array}{l}\text { Cross-sectional study design } \\
n=6 \text {; male } \\
\text { Inclusion criteria: all TE speakers } \\
\text { with Bivona-Colorado } \\
\text { low-resistance voice prosthesis } \\
\text { (Bivona Medical Technologies, } \\
\text { Gary, IN, USA) }\end{array}$ & $\begin{array}{l}\text { Interpolation method } \\
\text { Aerophone II (F.J. Electronics, Copenhagen, Denmark) } \\
\text { Pressure transducer calibration was done }\end{array}$ & $\begin{array}{l}\text { /pi/ syllable } \\
\text { repetition }\end{array}$ \\
\hline $\begin{array}{l}\text { Grolman et al. } \\
{[27], 2007}\end{array}$ & $\begin{array}{l}\text { Cross-sectional study design } \\
n=8 \\
\text { Inclusion criteria: all TE speakers } \\
\text { had to be tracheostoma valve users } \\
\text { in daily life }\end{array}$ & $\begin{array}{l}\text { Intraesophageal pressure method } \\
\text { It was measured by a mikro-Tip pressure transducer } \\
\text { (Millar Instruments, Houston, TX, USA) positioned at } \\
\text { voice prosthesis in the esophagus } \\
\text { Calibration of sensors was done }\end{array}$ & $\begin{array}{l}\text { Sustained } \\
\text { vowel /a/ }\end{array}$ \\
\hline $\begin{array}{l}\text { Kotby et al. } \\
{[34], 2009}\end{array}$ & $\begin{array}{l}\text { Cross-sectional study design } \\
n=18 \text {; male } \\
\text { Inclusion criteria: TE speakers }\end{array}$ & $\begin{array}{l}\text { Intraesophageal pressure method } \\
\text { A tube (inside diameter, } 3 \mathrm{~mm} \text {; outside diameter, } 4.1 \mathrm{~mm} \text { ) } \\
\text { was passed through the nasal cavity and introduced into } \\
\text { the upper esophagus, and secured at a distance of } 15 \mathrm{~cm} \\
\text { from the upper central incisors } \\
\text { The other end of the tube was connected to the oral } \\
\text { pressure input of the PERCI-SARS apparatus }\end{array}$ & $\begin{array}{l}\text { Sustained } \\
\text { vowel /a/ }\end{array}$ \\
\hline $\begin{array}{l}\text { Bohnenkamp } \\
\text { et al. [33], } 2011\end{array}$ & $\begin{array}{l}\text { Cross-sectional study design } \\
n=5 \text {; male; } 50-81 \text { years (mean } \\
61.20, \text { SD } 11.05 \text { years) } \\
\text { Inclusion criteria: TE speakers with } \\
\text { Blom-Singer voice prosthesis }\end{array}$ & \multirow{2}{*}{$\begin{array}{l}\text { Interpolation method } \\
\text { Pressure signals (model MA-IL, Glottal Enterprises) } \\
\text { were transduced and amplified (model MS100S, Glottal } \\
\text { Enterprises) after calibration (MCU-4, Glottal Enterprises) } \\
\text { The pressure and flow signals were processed through } \\
\text { wideband and low-frequency transducers (PTW-2, Glottal } \\
\text { Enterprises) } \\
\text { Speech and oral air pressure was low-pass filtered (cutoff } \\
\text { frequency, } 9 \mathrm{kHz} \text { ) and sampled at } 22 \mathrm{kHz} \text { by use of the } \\
\text { time-frequent analysis 32-bit (TF32) aeros analysis software }\end{array}$} & \multirow[t]{2}{*}{$\begin{array}{l}\text { /pa/ syllable } \\
\text { repetition }\end{array}$} \\
\hline $\begin{array}{l}\text { Bohnenkamp } \\
\text { et al. [32], } 2012\end{array}$ & $\begin{array}{l}\text { Cross-sectional study design } \\
n=6 ; \text { male; } 50-81 \text { years (mean 62.1, } \\
\text { SD } 10.28 \text { years) } \\
\text { Inclusion criteria: TE speakers } \\
\text { with Blom-Singer voice prosthesis }\end{array}$ & & \\
\hline
\end{tabular}

objectivity in evaluation of TE voice and subsequently aids in planning voice therapy for this population. Results of the current review found the pooled mean of SNP $(\mathrm{cm}$ $\mathrm{H}_{2} \mathrm{O}$ ) determined from the direct method to be greater than that determined from the indirect method. In TE speakers, the intratracheal pressure was measured by placing a polyethylene catheter into the tracheostoma with the proximal end connected to a differential pressure 


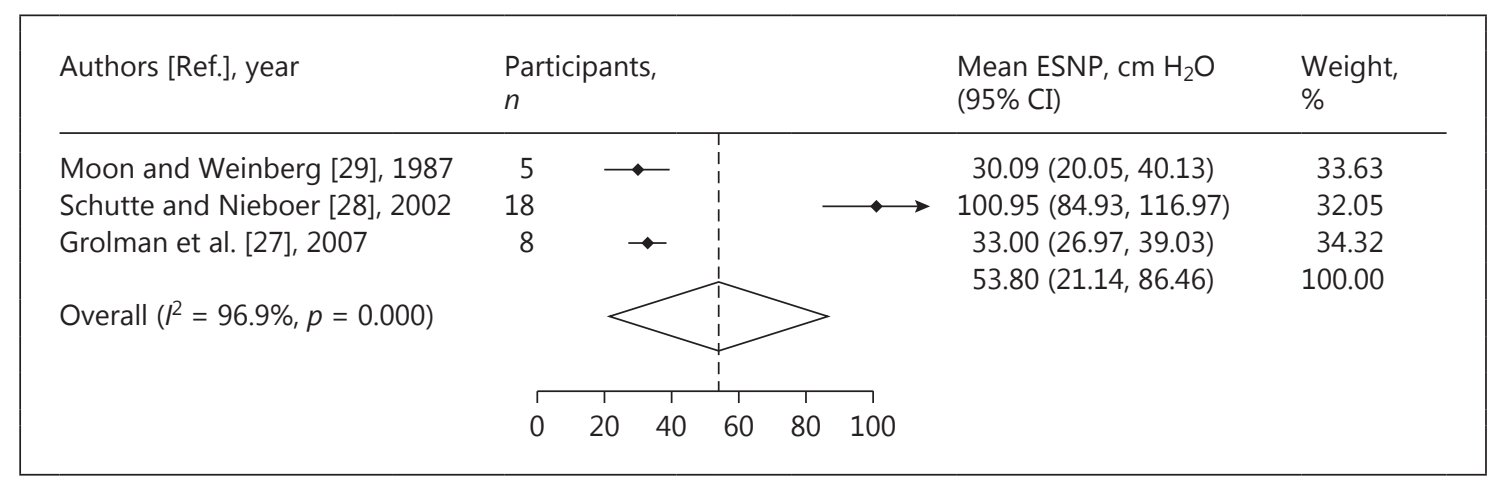

Fig. 1. Forest plot of $\mathrm{SNP}\left(\mathrm{cm} \mathrm{H}_{2} \mathrm{O}\right)$ obtained from the direct measurement method in TE speakers. Note: weights are from random-effects analysis.

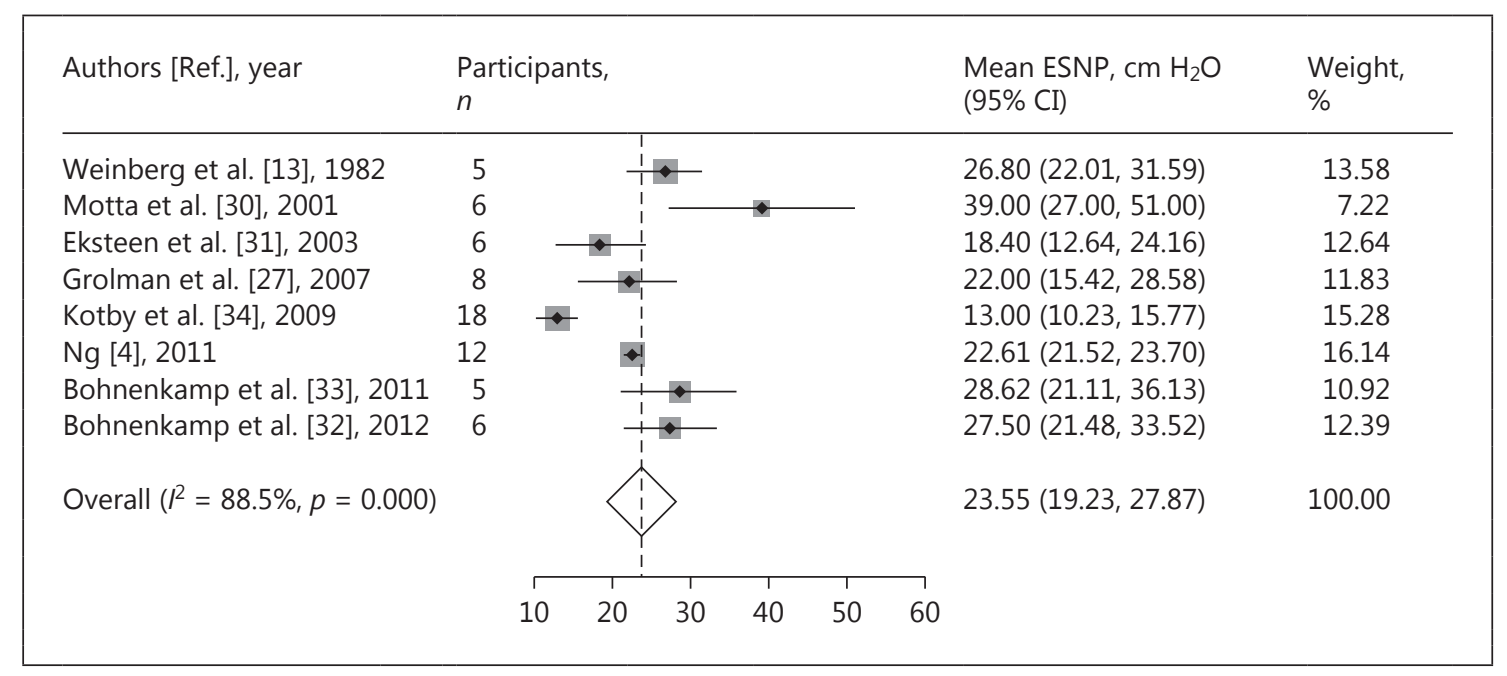

Fig. 2. Forest plot of SNP $\left(\mathrm{cm} \mathrm{H}_{2} \mathrm{O}\right)$ obtained from the indirect measurement method in TE speakers. Note: weights are from random-effects analysis.

transducer to determine SNP $\left(\mathrm{cm} \mathrm{H}_{2} \mathrm{O}\right)$. The measured pressure value reflects the summation of SNP $\left(\mathrm{cm} \mathrm{H}_{2} \mathrm{O}\right)$ and the pressure drop across the voice prosthesis $[27,28]$. In TE speakers, it has been stated that measuring the intratracheal pressure using the above procedure would help in measuring the transprosthesis pressure [27]. Hence, the direct estimation of SNP $\left(\mathrm{cm} \mathrm{H}_{2} \mathrm{O}\right)$ using the intratracheal method has yielded higher pressure values in TE speakers, which is not a valid representation of SNP $\left(\mathrm{cm} \mathrm{H}_{2} \mathrm{O}\right)$. Among studies considered [27-29], it was observed that there was (1) no mention of the voice prosthesis type [27], (2) mention of a particular type [28], or (3) mention of different types of voice prosthesis with respect to 5 participants considered in a study [29] (Table 3).
Therefore, meta-analysis was limited to the type of measurement methods used. Further research with respect to voice prosthesis type details are required to quantify the transprosthesis pressure differences.

$\mathrm{SNP}\left(\mathrm{cm} \mathrm{H}_{2} \mathrm{O}\right)$ obtained from determining the tracheal pressure by inserting a hypodermic needle through a stoma valve into the trachea is difficult to compare with the SNP $\left(\mathrm{cm} \mathrm{H}_{2} \mathrm{O}\right)$ obtained by the indirect method using esophageal pressure in which a tube-balloon unit is placed at the upper esophagus via the nose. This is due to the tracheal pressure reflecting the influence of the TE voice source (PE segment) along with the voice prosthesis. However, these two components are presumed to form the integral parts of TE voice production [29]. Studies us- 
ing normal laryngeal speakers through the use of the drop in intraesophageal pressure, which results when phonation is interrupted with the vocal fold abducted and lung volume held constant, are considered to provide a valid estimate of SGP under conditions of sustained phonation [5].

$\mathrm{SNP}\left(\mathrm{cm} \mathrm{H}_{2} \mathrm{O}\right)$ values obtained from the indirect measurement such as the interpolation method [4, 30-33] probably depend on the proper recording methodology and analysis of the IOP in TE speakers. It is appropriate to recall the reports of SGP $\left(\mathrm{cm} \mathrm{H}_{2} \mathrm{O}\right)$ estimated from the IOP $\left(\mathrm{cm} \mathrm{H}_{2} \mathrm{O}\right)$ in normal laryngeal speakers, which clearly indicated that the syllable string, syllable rate, lip closed quotient, loudness, pitch, articulation, oral pressure signal type, location on oral pressure signal used to estimate SGP $\left(\mathrm{cm} \mathrm{H}_{2} \mathrm{O}\right)$, equipment calibration, and frequency response are the factors to be considered [17].

On observation of the forest plot of SNP $\left(\mathrm{cm} \mathrm{H}_{2} \mathrm{O}\right)$ measured from the direct method (Fig. 1), a wider CI width of 21.14-86.46 $\mathrm{cm} \mathrm{H}_{2} \mathrm{O}$ was observed for the pooled mean of SNP $\left(\mathrm{cm} \mathrm{H}_{2} \mathrm{O}\right)$. This can be attributed to the difference in sample size, in turn revealing moderate heterogeneity $\left(I^{2}=96.9 \%\right)$. Among the 3 studies considered for the pooling of the SNP $\left(\mathrm{cm} \mathrm{H}_{2} \mathrm{O}\right)$ measured from the direct method, 2 studies $[28,29]$ had smaller sample sizes, but the study with the larger sample size [28] could have contributed to the wider CI width. As a result, the overall CI width at the $95 \%$ level was observed to be wider indicating a larger distance from the pooled mean.

Based on observation of the forest plot of SNP $(\mathrm{cm}$ $\mathrm{H}_{2} \mathrm{O}$ ) measured from the indirect method (Fig. 2), a majority of the studies intersected at the pooled estimate line indicating lesser variation from the estimated pooled mean $\left(23.55 \mathrm{~cm} \mathrm{H}_{2} \mathrm{O}\right)$. Further, a narrower $\mathrm{CI}$ width (19.23-27.87 $\mathrm{cm} \mathrm{H}_{2} \mathrm{O}$ ) for the overall pooled mean of $\mathrm{SNP}\left(\mathrm{cm} \mathrm{H}_{2} \mathrm{O}\right)$ revealed the consistency in the measured mean values across the studies, in spite of differences in the measurement procedures adopted in the indirect methods. However, 5 out of 8 studies [4, 30-33] using the interpolation method and 2 studies $[27,34]$ using the intraesophageal method should not be overlooked.

The current meta-analysis identified a substantial difference between the pooled means of SNP $\left(\mathrm{cm} \mathrm{H}_{2} \mathrm{O}\right)$ obtained from direct and indirect measurement methods in TE speakers and SGP in normal laryngeal speakers [18, $19,21]$. This difference can be due to changes in the respiratory system (reduced vital capacity; functional residual capacity, and mean expiratory flow rate), change in source of vibration (glottis to neoglottis) following total laryngectomy, change in vibrating principles (mass, length, and tension), and respiratory compromise due to typical age-related changes (loss of elasticity; recoil forces and reduced muscular forces) [14, 35-42]. Hence, SNP values obtained from the direct and indirect measurement methods in TE speakers may not be comparable with SGP obtained from normal laryngeal speakers. However, this difference needs to be further explained and confirmed with more comparative studies.

\section{Conclusion}

Measurement of SNP $\left(\mathrm{cm} \mathrm{H}_{2} \mathrm{O}\right)$ is essential to understand the aerodynamic aspects of TE speech. The current meta-analysis suggests that $\mathrm{SNP}\left(\mathrm{cm} \mathrm{H}_{2} \mathrm{O}\right)$ values obtained from the direct measurement cannot be compared with those obtained from the indirect measurement method in TE speakers. Further, it was revealed that the interpolation method for the indirect estimation of SNP $\left(\mathrm{cm} \mathrm{H}_{2} \mathrm{O}\right)$ is the most acceptable and valid method in TE speakers. This information should be useful to speechlanguage pathologists in the management of TE speakers for optimal voice quality outcomes.

\section{Acknowledgement}

Sincere thanks to Cancer Aid and Research Foundation (CARF) and Prof. Bellur Rajashekhar, Chair in Head and Neck Cancer Research and Voice Restoration, Manipal Academy of Higher Education, India, for funding support.

\section{Disclosure Statement}

The authors have no conflict of interest to declare.

References

1 Sapienza CM, Ruddy BH: Voice Disorders. San Diego, Plural Publishing, 2009.

2 Dejonckere PH: Perceptual and laboratory assessment of dysphonia. Otolaryngol Clin North Am 2000;33:731-50.

3 Nayak U, Kazi R (eds): Voice Restoration after Total Laryngectomy: Current Science and Future Perspectives. Byword Books Private Limited, 2009.

4 Ng ML: Aerodynamic characteristics associated with oesophageal and tracheoesophageal speech of Cantonese. Int J Speech Lang Pathol 2011;13:137-144.

5 Kunze LH: Evaluation of methods of estimating sub-glottal air pressure. J Speech Lang Hear Res 1964;7:151-164. 
-6 Koike Y, Perkins WH: Application of a miniaturized pressure transducer for experimental speech research. Folia Phoniatr Logop 1968;20:360-368.

$>7$ Van den Berg JW: Direct and indirect determination of the mean subglottic pressure. Folia Phoniatr Logop 1956;8:1-24.

$>8$ Draper MH, Ladefoged P, Whitteridge D: Expiratory pressures and air flow during speech. Br Med J 1960;1:1837.

-9 Lieberman P: Direct comparison of subglottal and esophageal pressure during speech. J Acoust Soc Am 1968;43:1157-1164.

10 Smitheran JR, Hixon TJ: A clinical method for estimating laryngeal airway resistance during vowel production. J Speech Hear Disord 1981; 46:138-146.

-11 Rothenberg M: Interpolating subglottal pressure from oral pressure. J Speech Hear Disord 1982;47:219- 220.

12 Logemann JA: The evaluation and treatment of swallowing disorders. Curr Opin Otolaryngol Head Neck Surg 1998;6:395-400.

$>13$ Weinberg B, Horii Y, Blom E, Singer M: Airway resistance during esophageal phonation. J Speech Hear Disord 1982;47:194-199.

14 Bohnenkamp TA: Speech Breathing in Tracheoesophageal Speakers. ProQuest, 2006.

15 Fisher KV, Swank PR: Estimating phonation threshold pressure. J Speech Lang Hear Res 1997;40:1122-1129.

$>16$ Enflo L, Sundberg J: Vocal fold collision threshold pressure: An alternative to phonation threshold pressure? Logoped Phoniatr Vocol 2009;34:210-217.

17 Frazer BL: Approximating Subglottal Pressure from Oral Pressure: A Methodological Study; doctoral dissertation, Bowling Green State University, 2014.

18 Löfqvist A, Carlborg B, Kitzing P: Initial validation of an indirect measure of subglottal pressure during vowels. J Acoust Soc Am 1982;72:633-635.

-19 McHenry M, Minton JT, Kuna ST, Vanoye CR, Roberts-Seibert NS: Comparison of direct and indirect calculations of laryngeal airway resistance in various voicing conditions. Eur J Disord Commun 1995;30:435-449.
20 Hertegård S, Gauffin J, Lindestad PÅ: A comparison of subglottal and intraoral pressure measurements during phonation. J Voice 1995;9:149-155.

21 Kitajima K, Fujita F: Estimation of subglottal pressure with intraoral pressure. Acta Otolaryngol 1990;109:473-478.

22 Higgins JP, Green S, eds: Cochrane Handbook for Systematic Reviews of Interventions. John Wiley \& Sons, 2011.

23 Liberati A, Altman DG, Tetzlaff J, Mulrow C, Gøtzsche PC, Ioannidis JP, Clarke M, Devereaux PJ, Kleijnen J, Moher D: The PRISMA statement for reporting systematic reviews and meta-analyses of studies that evaluate health care interventions: explanation and elaboration. PLoS Med 2009;6:e1000100.

24 Blom ED: Evolution of tracheoesophageal voice prostheses; in Blom ED, Singer MI, Hamaker RC (eds): Tracheoesophageal Voice Restoration following Total Laryngectomy. San Diego, Singular Publishing Group, 1998, pp 1-8.

25 Leydon C, Wroblewski M, Eichorn N, Sivasankar M: A meta-analysis of outcomes of hy dration intervention on phonation threshold pressure. J Voice 2010;24:637-643.

26 Berman NG, Parker RA: Meta-analysis: neither quick nor easy. BMC Med Res Methodol 2002;2:10.

27 Grolman W, Eerenstein SE, Tan FM, Tange RA, Schouwenburg PF: Aerodynamic and sound intensity measurements in tracheoesophageal voice. ORL 2007;69:68-76.

28 Schutte HK, Nieboer GJ: Aerodynamics of esophageal voice production with and without a Groningen voice prosthesis. Folia Phoniatr Logop 2002;54:8-18.

-29 Moon JB, Weinberg B: Aerodynamic and myoelastic contributions to tracheoesophageal voice production. J Speech Hear Res 1987;30:387-395.

30 Motta S, Galli I, Di Rienzo L: Aerodynamic findings in esophageal voice. Arch Otolaryngol Head Neck Surg 2001;127:700-704.
31 Eksteen EC, Reiger JC, Nesbitt M, Seikaly H: Comparison of voice characteristics following three different methods of treatment for laryngeal cancer. J Otolaryngol 2003;32:250253.

32 Bohnenkamp TA, Forrest K, Klaben BK, Stager J: Chest wall kinematics during speech breathing in tracheoesophageal speakers. Ann Otol Rhinol Laryngol 2012;121:28-37.

33 Bohnenkamp TA, Forrest KM, Klaben BK, Stager JM: Lung volumes used during speech breathing in tracheoesophageal speakers. Ann Otol Rhinol Laryngol 2011;120:550-558.

34 Kotby MN, Hegazi MA, Kamal I, Gamal El Dien N, Nassar J: Aerodynamics of the pseudo-glottis. Folia Phoniatr Logop 2009;61:2428.

35 Usui N: Ventilatory function in laryngectomized patients. Auris Nasus Larynx 1979;6: 87-96.

36 Togawa K, Konno A, Hoshino T: A physiologic study on respiratory handicap of the laryngectomized. Arch Otorhinolaryngol 1980; 229:69-79.

37 Gregor RT, Hassman E: Respiratory function in post-laryngectomy patients related to stomal size. Acta Otolaryngol 1984;97:177-183.

38 Todisco TT, Maurizi M, Paludetti G, Dottorini M, Merante F: Laryngeal cancer: long-term follow-up of respiratory functions after laryngectomy. Respiration 1984;45:303-315.

39 Murty GE, Smith MC, Lancaster P: Cough intensity in the laryngectomee. Clin Otolaryngol 1991;16:25-28.

40 Ackerstaff AH, Hilgers FJ, Balm AJ, Zandwijk $\mathrm{N}$ : Long-term pulmonary function after total laryngectomy. Clin Otolaryngol 1995;20: 547-551.

41 Ackerstaff AH, Hilgers FJ, Balm AJ, Tan IB: Long-term compliance of laryngectomized patients with a specialized pulmonary rehabilitation device. Laryngoscope 1998;108: 257-260.

42 Hess MM, Schwenk RA, Frank W, Loddenkemper R: Pulmonary function after total laryngectomy. Laryngoscope 1999;109:988-994. 